\title{
Transcriptome analysis identifies novel responses and potential regulatory genes involved in seasonal dormancy transitions of leafy spurge (Euphorbia esula L.)
}

\author{
David P Horvath*1, Wun S Chao1, Jeffrey C Suttle², Jyothi Thimmapuram² \\ and James $\mathrm{V}$ Anderson ${ }^{1}$
}

Address: ${ }^{1}$ Biosciences Research Laboratory, USDA-Agricultural Research Service, Fargo ND, USA, ${ }^{2}$ Northern Crop Science Laboratory, USDAAgricultural Research Service, Fargo ND, USA and ${ }^{3}$ WM Keck Center for Comparative and Functional Genomics, University of Illinois, Urbana IL, USA

Email: David P Horvath* - david.horvath@ars.usda.gov; Wun S Chao - wun.chao@ars.usda.gov; Jeffrey C Suttle - jeffrey.suttle@ars.usda.gov; Jyothi Thimmapuram - jyothit@uiuc.edu; James V Anderson - james.anderson@ars.usda.gov

* Corresponding author

Published: 12 November 2008

BMC Genomics 2008, 9:536 doi:10.1186/147|-2164-9-536
Received: 15 August 2008

Accepted: 12 November 2008

This article is available from: http://www.biomedcentral.com/I47I-2/64/9/536

(c) 2008 Horvath et al; licensee BioMed Central Ltd.

This is an Open Access article distributed under the terms of the Creative Commons Attribution License (http://creativecommons.org/licenses/by/2.0), which permits unrestricted use, distribution, and reproduction in any medium, provided the original work is properly cited.

\begin{abstract}
Background: Dormancy of buds is a critical developmental process that allows perennial plants to survive extreme seasonal variations in climate. Dormancy transitions in underground crown buds of the model herbaceous perennial weed leafy spurge were investigated using a $23 \mathrm{~K}$ element cDNA microarray. These data represent the first large-scale transcriptome analysis of dormancy in underground buds of an herbaceous perennial species. Crown buds collected monthly from August through December, over a five year period, were used to monitor the changes in the transcriptome during dormancy transitions.

Results: Nearly I,000 genes were differentially-expressed through seasonal dormancy transitions. Expected patterns of gene expression were observed for previously characterized genes and physiological processes indicated that resolution in our analysis was sufficient for identifying shifts in global gene expression.

Conclusion: Gene ontology of differentially-expressed genes suggests dormancy transitions require specific alterations in transport functions (including induction of a series of mitochondrial substrate carriers, and sugar transporters), ethylene, jasmonic acid, auxin, gibberellic acid, and abscisic acid responses, and responses to stress (primarily oxidative and cold/drought). Comparison to other dormancy microarray studies indicated that nearly half of the genes identified in our study were also differentially expressed in at least two other plant species during dormancy transitions. This comparison allowed us to identify a particular MADS-box transcription factor related to the DORMANCY ASSOCIATED MADS-BOX genes from peach and hypothesize that it may play a direct role in dormancy induction and maintenance through regulation of FLOWERING LOCUS $T$.
\end{abstract}




\section{Background}

Leafy spurge (Euphorbia esula L.) is a perennial range land weed that infests the great plains of the US and Canada. This invasive and noxious weed maintains its perennial growth habit through the seasonal production of numerous underground adventitious buds on the lateral roots and crown (an underground portion of the stem derived originally from the hypocotyl). Crown and root buds of leafy spurge are capable of manifesting the three types of dormancy (para-, endo- and ecodormancy) described by Lang et al. [1]. In general, new leafy spurge crown buds become visible in late May to early June, following flowering, and progressively enlarge throughout the summer and fall seasons [2]. These crown buds, once formed, will not initiate new shoot growth unless the top of the plant is destroyed. Thus, initiation of new shoot growth is inhibited in newly formed crown and root buds during the growing season (usually from April to October) by mechanisms akin to apical dominance, or paradormancy. Studies on both crown and root buds indicate that two separate signals produced by the aerial portion of the plant are capable of maintaining bud dormancy [3]. These signals are auxin, likely acting through previously described mechanisms [4,5] and sugar acting through $\mathrm{ABA} / \mathrm{GA}$ signalling that appear to regulate the G1 to $\mathrm{S}$ transition of the cell cycle $[6,7]$.

Depending on yearly environmental conditions, crown buds of leafy spurge transition from paradormancy through endodormancy and into ecodormancy between early October and the middle of November [2]. This transition is important since early frosts could destroy the aerial portion of the plant, and thus initiate new shoot growth which would in turn be vulnerable to later frosts. Indeed, plants which are moved into growth-conducive conditions following the transition to endodormancy will not readily initiate new growth even if the above-ground portion of the plant is removed, suggesting that signals within the buds themselves inhibits growth. After an extended period of cold temperatures (usually coinciding with an average bare soil temp of $0^{\circ} \mathrm{C}$ which generally occurs by late November or early December in the location tested), crown buds are released from endodormancy and concomitantly become flowering competent [2]. However, by this time, consistently cold winter conditions induce a state of ecodormancy which blocks new shoot growth from the buds until spring conditions allow for renewed growth. We are interested in understanding the physiological processes involved in signals regulating the transitions between para-, endo- and ecodormancy.

There is emerging but incomplete information on the mechanisms by which dormancy transitions occur in adventitious buds of perennials. Chouard [8] noted commonalities between environmental signals and condi- tions regulating both vernalization (and hence flowering competence) and breaking of endodormancy. These observations have been recently reiterated and extended to develop a hypothesis that the signalling pathways regulating endodormancy induction and breaking might share components with those regulating flowering competency $[9,10]$. Indeed, work by Böhlenius [11] has demonstrated that constitutive expression of a flowering regulatory gene in poplar (Populus trichocarpa) FLOWERING LOCUS T (FT), is sufficient for preventing seasonal growth cessation induced by short day conditions. Likewise, over-expression of PHYA prevented short dayinduced repression of PtFT2 in the leaves, and CENTRORADIALIS-LIKE 1 (CENL1), a gene related to FT but with opposite effect on flowering, in the rib meristem [12]. Indeed, the same study went on to show that PHYA overexpression prevented endodormancy per se. Combined, these data suggest that short day-induced growth cessation is the first step towards endodormancy induction, and that this first step can be impacted by expression of FT and related genes.

A mutation in peach caused by a deletion of a locus containing several tandomly duplicated MADS-box transcription factors, known as evergrowing (evg), prevents dormancy induction [13-15]. Similar genes were differentially expressed following dormancy transitions in raspberry (Rubus idaeus L.) and apricot (Prunus mume) [16,17]. These MADS-box genes (named DORMANCY ASSOCIATED MADSBOX or DAM genes) are related to SHORT VEGETATIVE PHASE (SVP) and AGAMOUS LIKE24 (AGL24) of Arabidopsis but form a separate clade within this group [15]. In Arabidopsis, mutations in SVP promote early flowering [18]. Interestingly, experimental evidence indicates that SVP negatively regulates expression of FT in Arabidopsis by binding to its promoter [19]. AGL24, a floral promoter, is up-regulated during vernalization [20]. Analysis of publicly available microarray data indicate that both AGL24 and SVP are preferentially expressed during short day (SD) conditions relative to long day in micro-dissected apical tissue harvested 0, 3, 5, and 7 days after the shift to LD. Thus, SVP and AGL24 are regulated by environmental conditions known to impact bud dormancy in perennial species.

In addition to DAM genes and FT/CENL1 with known or suspected involvement in bud dormancy/growth, several studies have been done on the impact of various dormancy transitions on the whole transcriptome of buds in kiwi fruit (Actinidia deliciosa), grape (Vitis riparia), raspberry, potato (Solanum tuberosum), and in the terminal buds and cambial meristem of poplar (Populus tremuloidies) [21,22,16,23-25], Marion Wood-personal communication. These studies have shown that dormancy signals impact numerous physiological processes including cell 
division, oxidative stress, and flavone biosynthesis. Additionally, these studies have demonstrated changes in expression patterns of numerous known regulatory genes that could play a vital role in dormancy transitions, or in regulating physiological processes impacted by dormancy transitions. However, no comparison of these bud dormancy data sets has yet been done.

Understanding the molecular mechanisms involved in regulating dormancy transitions in leafy spurge should provide information needed to control this invasive weed. Additionally, as there appears to be considerable conservation in the mechanisms regulating dormancy in other perennial systems, information gained on the mechanisms regulating dormancy transitions in leafy spurge could be used to develop means to control this critical process in other perennial crops, horticultural species, and weeds. We used newly developed high density cDNA microarrays which contained $>19,000$ unigenes sequences from leafy spurge. Additionally, the arrays contained $>4,000$ unigenes from cassava (Manihot esculenta Crantz), a related species, that generally hybridize to leafy spurge CDNAs [26] but which were not present in the leafy spurge EST collection. This array was used to follow transcriptome changes associated with dormancy transitions in leafy spurge over a 5 year period. Changes associated with each specific dormancy transition (para to endo and endo to eco) are noted, and commonalities between these results and other transcriptomic analyses of dormancy were identified.

\section{Results \\ Transcriptome analysis identifies differentially expressed genes}

Changes in the transcriptome of leafy spurge crown buds samples, collected monthly from August to December for 5 consecutive years (2002-2006), were obtained by microarray analyses (GEO accession \# GSE8849). From nearly 22,000 different unigene probes that showed consistent hybridization, about 1400 were identified as differentially expressed ( $p$ value $<0.005$ ) based on ANOVA of samples grouped by month. Cluster analysis of these 1400 genes indicated that the monthly samples fell into two main groups (Figure 1). One group contained crown bud samples collected in August and September along with three crown bud samples collected in October. The remaining cluster was roughly divided into four sub-clusters; two containing nearly all of the December crown bud samples and several November samples, with the remaining clusters made up of a mix of October and November

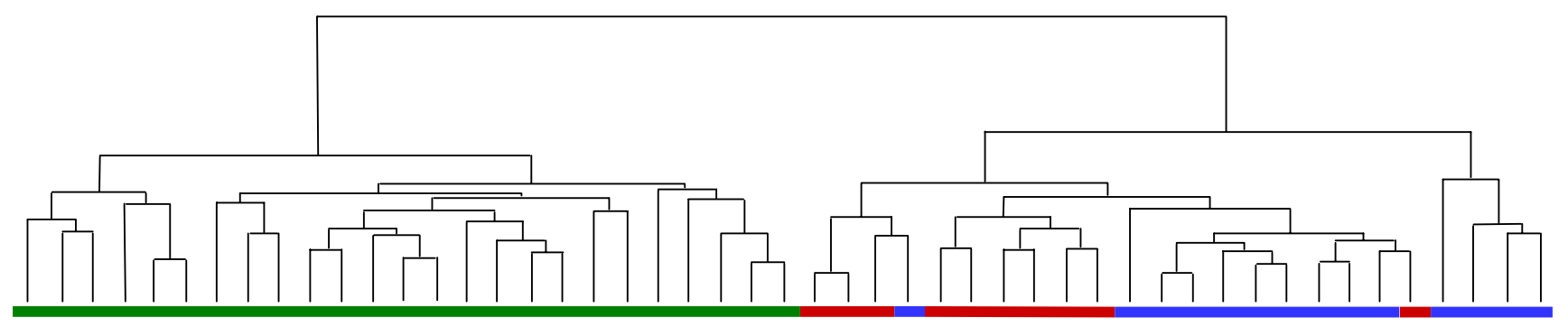

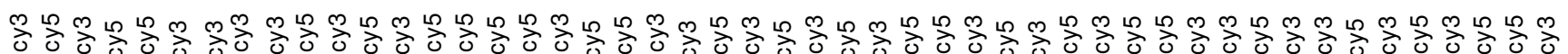

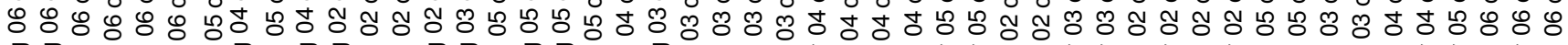

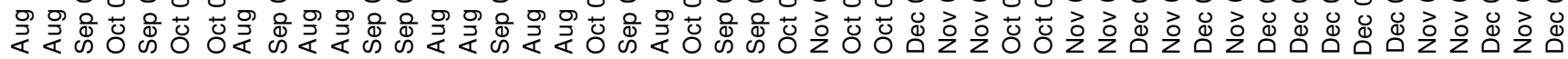

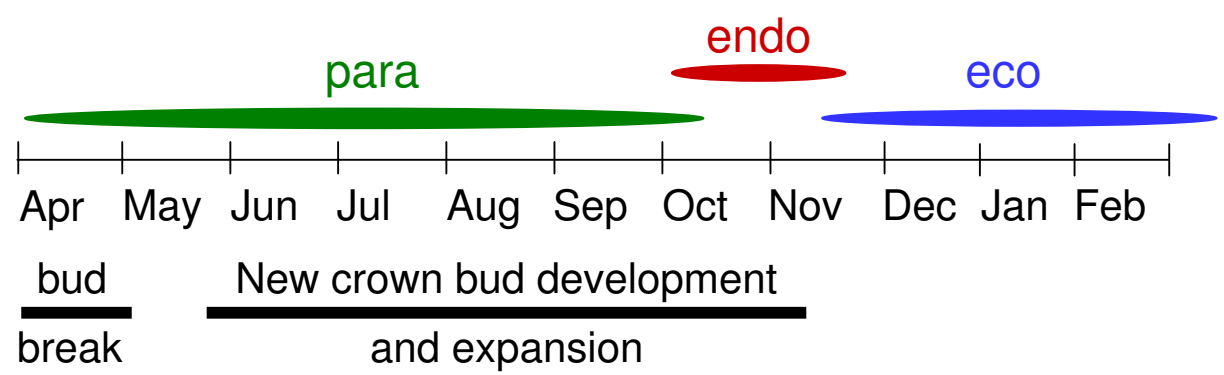

Figure I

Cluster analysis of expression data. Green lines indicate samples designated as paradormant, red lines indicate samples designated as endodormant, and blue lines indicate samples designated as ecodormant. Monthly representation of bud development growth and dormancy transitions is shown below. 
crown bud samples. The same clustering of samples based on expression was observed using principle component analysis and explained the majority of the variation observed in the data set (data not shown).

There is known yearly variability associated with the transition of crown buds into and out of endodormancy (Anderson J.V., personal communication). Thus, these results were interpreted to mean that the cluster containing all the August and September samples represented crown buds still in paradormancy. Likewise, the clusters containing December and November samples were considered to represent buds that were ecodormant and flowering competent. The remaining sub-clusters were considered to be endodormant. P-values and q-values based on differences between samples from the three dormancy states identified 999 genes with significant p-values $(\mathrm{p}<0.005)$.

Probable Arabidopsis orthologues, MIPS designations, KOG\#, GO annotations, and BLASTX hits were determined for these probes when possible (see Additional file 1). GO annotations indicated genes involved in jasmonic acid signalling, unidimensional cell growth, and transport were significantly over-represented among the differentially-expressed genes (Table 1). MIPS annotation suggested that genes involved in protein fate, protein synthesis, cellular communication, energy, protein binding, development, and cell fate were the most significantly over-represented (Table 2).

MAPMAN analysis indicated that genes involved in metabolic pathways for glycolysis, transport (calcium and major intrinsic proteins), protein synthesis initiation, auxin responses, and redox regulation were the most overrepresented (Table 3). Surprisingly, although glycolysis genes were both over-represented and generally induced through the dormancy transitions, almost none of the genes involved in the TCA cycle were present among the differentially-expressed genes.

BLASTX searches for possible gene function indicated that numerous genes with similarity to known or suspected cold stress response genes were up-regulated in fall and winter. Likewise, numerous genes with similarity to known or suspected cell division genes were generally down-regulated through seasonal transitions from summer to winter. There were also many genes with similarities to transport associated functions that were preferentially expressed as dormancy progressed from the fall through the winter (See Additional file 2). Some specific differentially-expressed genes of note included a SWITCHING2/SUCROSE NON_FERMENTING2 (SWI2/ $S N F 2$ ) which encodes a protein known to play a role in chromatin remodelling [27], were steadily down-regu- lated during seasonal dormancy progression. Genes similar to EARLY FLOWERING 4 (ELF4), GIGANTEA (GI), CONSTANS (CO), FLAVIN BINDING KELCH REPEAT FBOX1 (FKF1), CIRCADIAN CLOCK ASSOCIATED1 (CCA1), PHYA, and several circadian-regulated PSEUDORESPONSE REGULATORS (PRRs) that are possible components of the circadian clock regulatory pathway $[28,29]$ are all up-regulated during the seasonal progression (from paradormancy through to ecodormancy).

Expression of a subset of differentially-expressed genes was confirmed by quantitative RT-PCR (Figure 2). Comparison of these genes suggests that the general trends in expression observed by microarray analysis are similar but somewhat muted as compared to that observed by RTPCR. $100 \%$ of the 27 genes tested by RT-PCR showed similar trends to those observed using microarray analysis, indicating the robustness of our analysis.

\section{Gene expression characteristics of different dormancy states}

Analyses were done to identify genes that showed differential expression unique to specific dormant states (See Additional file $3 \mathrm{a}-\mathrm{c}$ ). Only 16 genes were preferentially expressed during endodormancy (see Additional file $3 \mathrm{~b}$ ). One of these contains a helix-loop helix motif characteristic of DNA binding transcription factors, and another was similar to DROUGHT RESPONSIVE ELEMENT BINDING III (DREBIII), a transcription factor known to play a role in drought and cold responses in plants. Only 5 genes were significantly down-regulated specifically during endodormancy. Genes involved in flavanoid biosynthesis were relatively highly expressed during paradormancy and then down-regulated during endo- and ecodormancy. Likewise, several growth regulating genes such as GROWTH REGULATING FACTOR 5 (GRF5), a RETINOBLASTOMA-like, and ARABIDOPSIS MEI2 LIKE1 (AML1) are also preferentially expressed in ecodormant buds (see Additional file 2).

\section{Comparison to other dormancy microarray studies identifies common signals and processes}

There have been four other published microarray studies on bud dormancy in raspberry [16], poplar [23], potato [25] and grape [21]. Additionally, there are as yet unpublished studies completed on kiwifruit (Marion Wood et al., personal communication), and studies on seasonal dormancy in poplar cambial meristems $[22,24]$. TBlastX comparisons between the genes represented on the arrays from these various datasets (see Additional file 4) indicated that 431 leafy spurge genes were differentially expressed in both poplar buds induced into dormancy by SD and in our leafy spurge dataset (240 showed the same expression trend in the transition from paradormancy into endodormancy). Likewise, 722 were differentially 
Table I: Identification of over- and under-represented gene ontology (GO) terms in differentially-expressed gene set.

\begin{tabular}{|c|c|c|c|c|c|c|}
\hline $\begin{array}{l}\text { GO_Biological } \\
\text { function }\end{array}$ & $\begin{array}{l}\text { number of elements } \\
\text { on the array }\end{array}$ & $\begin{array}{l}\text { number of elements } \\
\text { differentially } \\
\text { expressed }\end{array}$ & $\begin{array}{l}\text { number of elements } \\
\text { expected to be } \\
\text { differentially expressed }\end{array}$ & $\begin{array}{l}\text { fold over or under } \\
\text { represented }\end{array}$ & $\mathrm{p}$-value & Adjusted $p$-value \\
\hline $\begin{array}{l}\text { response to jasmonic } \\
\text { acid stimulus }\end{array}$ & 46 & 12 & 1.83 & 6.63 & I.45E-07 & $3.93 \mathrm{E}-06$ \\
\hline $\begin{array}{l}\text { unidimensional cell } \\
\text { growth }\end{array}$ & 15 & 7 & 0.60 & 11.86 & $6.96 \mathrm{E}-07$ & $1.88 \mathrm{E}-05$ \\
\hline Transport & 317 & 32 & $|2.6|$ & 2.57 & I.19E-06 & $3.23 \mathrm{E}-05$ \\
\hline signal transduction & 91 & 9 & 3.62 & 2.51 & 0.01 & 0.26 \\
\hline $\begin{array}{l}\text { response to oxidative } \\
\text { stress }\end{array}$ & 61 & 7 & 2.43 & 2.92 & 0.01 & 0.27 \\
\hline $\begin{array}{l}\text { biological process } \\
\text { unknown }\end{array}$ & 5116 & 231 & 203.57 & 1.15 & 0.01 & 0.27 \\
\hline Metabolism & 507 & 31 & 20.17 & 1.55 & 0.01 & 0.29 \\
\hline circadian rhythm & 15 & 3 & 0.60 & 5.08 & 0.02 & 0.52 \\
\hline Growth & 8 & 2 & 0.32 & 6.35 & 0.04 & 1 \\
\hline $\begin{array}{l}\text { extracellular matrix } \\
\text { organization and } \\
\text { biogenesis }\end{array}$ & 1 & 1 & 0.04 & 25.42 & 0.04 & 1 \\
\hline cell death & 9 & 2 & 0.36 & 5.65 & 0.05 & 1 \\
\hline $\begin{array}{l}\text { response to hormone } \\
\text { stimulus }\end{array}$ & 2 & 1 & 0.08 & $12.7 \mid$ & 0.08 & 1 \\
\hline $\begin{array}{l}\text { response to } \\
\text { temperature stimulus }\end{array}$ & 2 & 1 & 0.08 & 12.71 & 0.08 & 1 \\
\hline response to stress & 43 & 4 & 1.71 & 2.36 & 0.09 & 1 \\
\hline response to cold & 3 & 1 & 0.12 & 8.47 & 0.11 & 1 \\
\hline $\begin{array}{l}\text { response to } \\
\text { wounding }\end{array}$ & 18 & 2 & 0.72 & 2.82 & 0.16 & 1 \\
\hline Aging & 20 & 2 & 0.80 & 2.54 & 0.18 & 1 \\
\hline $\begin{array}{l}\text { response to auxin } \\
\text { stimulus }\end{array}$ & 22 & 2 & 0.88 & 2.31 & 0.21 & 1 \\
\hline $\begin{array}{l}\text { gibberellic acid } \\
\text { mediated signaling }\end{array}$ & 10 & 1 & 0.40 & 2.54 & 0.33 & 1 \\
\hline $\begin{array}{l}\text { sugar mediated } \\
\text { signaling }\end{array}$ & 12 & 1 & 0.48 & 2.12 & 0.38 & 1 \\
\hline Biosynthesis & 105 & 5 & 4.18 & 1.21 & 0.40 & 1 \\
\hline defense response & 158 & 7 & 6.29 & 1.13 & 0.43 & 1 \\
\hline $\begin{array}{l}\text { response to water } \\
\text { deprivation }\end{array}$ & 15 & 1 & 0.60 & 1.69 & 0.45 & 1 \\
\hline $\begin{array}{l}\text { embryonic } \\
\text { development } \\
\text { (sensu } \\
\text { Magnoliophyta) }\end{array}$ & 23 & 1 & 0.92 & 1.11 & 0.60 & 1 \\
\hline response to heat & 30 & 1 & 1.19 & -1.18 & 0.70 & 1 \\
\hline photosynthesis & 37 & 1 & 1.47 & -1.46 & 0.77 & 1 \\
\hline Undetermined & 18420 & 631 & 732.96 & -1.15 & 1 & 1 \\
\hline
\end{tabular}

The number of differentially-expressed genes with a given GO annotation present on the array was used to determine the expected number of differentially-expressed genes with that annotation. The number of observed differentially expressed genes was compared to the expected number to provide a fold over or under representation. P-values and false discovery rates (adjusted P-values) were identified.

expressed in both potato tuber meristems during the transition from endodormancy directly to growth and during the endodormancy to ecodormancy transition in our leafy spurge dataset. In addition, 460 were differentially expressed in at least three species, and 11 were differentially expressed in all 5 species.

The putative function of the 110 differentially-expressed genes in four or more species suggest cell cycle, transport, stress, and GA responses are important conserved proc- esses affected by dormancy transitions. An analysis of genes differentially expressed in three or more species also identified these same processes and additional common features included circadian-regulated genes, ABA/auxin/ light regulatory and responsive genes, and genes encoding transport functions and flavanoid biosynthesis. Differentially regulated transcription factors found in 3 or more species included the DAM genes, AGAMOUS LIKE63, BLIND, DREB/CBF, INDUCER OF CBF EXPRESSION (ICE1), HOMEOBOX3 (HOX3), 4 MYB, 3 MYC, HEX- 
Table 2: Analysis of over- and under-represented MIPS annotations terms for differentially-expressed gene set

\begin{tabular}{|c|c|c|c|c|c|c|}
\hline MIPS FUNCTION & $\begin{array}{l}\text { number of } \\
\text { elements on the } \\
\text { array }\end{array}$ & $\begin{array}{l}\text { number of elements } \\
\text { differentially } \\
\text { expressed }\end{array}$ & $\begin{array}{l}\text { number of elements } \\
\text { expected to be } \\
\text { differentially } \\
\text { expressed }\end{array}$ & $\begin{array}{l}\text { fold over or under } \\
\text { represented }\end{array}$ & $\mathrm{p}$-value & adjusted $\mathrm{p}$-value \\
\hline $\begin{array}{l}\text { SUBCELLULAR } \\
\text { LOCALIZATION }\end{array}$ & 1263 & 3 & 50.25 & -16.75 & 0 & 0 \\
\hline $\begin{array}{l}\text { PROTEIN FATE } \\
\text { (folding, modification, } \\
\text { destination) }\end{array}$ & 633 & 6 & 25.17 & -4.20 & $9.1 I E-07$ & I.64E-05 \\
\hline PROTEIN SYNTHESIS & 525 & 4 & 20.88 & -5.22 & $1.18 \mathrm{E}-06$ & 2.12E-05 \\
\hline $\begin{array}{l}\text { CELLULAR } \\
\text { COMMUNICATION/ } \\
\text { SIGNAL } \\
\text { TRANSDUCTION } \\
\text { MECHANISM }\end{array}$ & 741 & 9 & 29.47 & -3.27 & $2.26 \mathrm{E}-06$ & 4.07E-05 \\
\hline ENERGY & 439 & 3 & 17.48 & -5.83 & $3.55 \mathrm{E}-06$ & $6.38 \mathrm{E}-05$ \\
\hline $\begin{array}{l}\text { PROTEIN WITH } \\
\text { BINDING FUNCTION } \\
\text { OR COFACTOR } \\
\text { REQUIREMENT } \\
\text { (structural or catalytic) }\end{array}$ & 618 & 7 & 24.58 & -3.51 & 6.7IE-06 & I.2IE-04 \\
\hline $\begin{array}{l}\text { DEVELOPMENT } \\
\text { (Systemic) }\end{array}$ & 261 & 1 & 10.39 & -10.39 & 2.67E-05 & $4.8 \mathrm{E}-04$ \\
\hline CELL FATE & 256 & 2 & 10.19 & -5.09 & 3.79E-04 & $6.82 \mathrm{E}-04$ \\
\hline $\begin{array}{l}\text { INTERACTION WITH } \\
\text { THE CELLULAR } \\
\text { ENVIRONMENT }\end{array}$ & 146 & 2 & 5.79 & -2.90 & 0.02 & 0.37 \\
\hline $\begin{array}{l}\text { BIOGENESIS OF } \\
\text { CELLULAR } \\
\text { COMPONENTS }\end{array}$ & 542 & 12 & 21.58 & -1.80 & 0.01 & 0.17 \\
\hline $\begin{array}{l}\text { CELL CYCLE AND DNA } \\
\text { PROCESSING }\end{array}$ & 289 & 7 & 11.49 & -1.64 & 0.06 & 1 \\
\hline TRANSCRIPTION & 726 & 24 & 28.87 & -1.20 & 0.17 & 1 \\
\hline $\begin{array}{l}\text { CELL RESCUE, DEFENSE } \\
\text { AND VIRULENCE }\end{array}$ & 577 & 21 & 22.977 & -1.09 & 0.33 & 1 \\
\hline $\begin{array}{l}\text { CELLULAR } \\
\text { TRANSPORT, } \\
\text { TRANSPORT } \\
\text { FACILITATION AND } \\
\text { TRANSPORT ROUTES }\end{array}$ & 758 & 28 & 30.17 & -1.08 & 0.34 & 1 \\
\hline $\begin{array}{l}\text { CLASSIFICATION NOT } \\
\text { YET CLEAR-CUT }\end{array}$ & 1072 & 44 & 42.66 & 1.03 & 0.59 & 1 \\
\hline $\begin{array}{l}\text { UNCLASSIFIED } \\
\text { PROTEINS }\end{array}$ & 14494 & 711 & 565.43 & 1.26 & I & 1 \\
\hline METABOLISM & 1737 & 111 & 69.13 & 1.61 & 1 & 1 \\
\hline STORAGE PROTEIN & 30 & 4 & 1.20 & 3.34 & 0.97 & 1 \\
\hline
\end{tabular}

The number of differentially-expressed genes with a given MIPS annotation present on the array was used to determine the expected number of differentially-expressed genes with that annotation. The number of observed differentially expressed genes was compared to the expected number to provide a fold over or under representation. P-values and false discovery rates (adjusted P-values) were identified.

AMER BINDING PROTEIN-1b (HBP-1b), HOX 4, WRKY (A1244, 30, 53), and nine different zinc finger-encoding genes. One MYB and one zinc finger-containing transcription factor were among those genes noted as commonly differentially-expressed in poplar buds, cambial meristems, and seed dormancy transitions [23]. Only 41 other genes were differentially expressed during dormancy transitions in both Arabidopsis seed and leafy spurge buds, and of these, only 16 were expressed in a similar manner in response to dormancy transitions (data not shown). No obvious signals or pathways were common to both seed and bud dormancy transitions were detected.

\section{ABA levels drop following endo- to ecodormancy transition} ABA levels are correlated with bud dormancy in several species and tend to drop as buds transition through ecodormancy [30-32]. However, very few putative ABA-regulated genes were down-regulated (see Additional file 2). To determine if ABA levels changed between endo and ecodormancy, ABA levels were measured over two years in 
Table 3: MAPMAN analysis of over- and under-represented physiological processes for differentially-expressed gene set.

\begin{tabular}{llll}
\hline BIN & Function & elements & P-value \\
\hline 4 & glycolysis & 8 & 0.0001 \\
34.19 .1 & transport major intrinsic proteins, PIP & 4 & 0.0090 \\
21 & redox, regulation & 6 & 0.0119 \\
29.2 .3 & protein synthesis, initiation & 4 & 0.0308 \\
34.21 & transport, calcium & 3 & 0.0451 \\
17.2 & hormone metabolism, auxin & 3 & 0.0464 \\
\hline
\end{tabular}

The probability ( $p$-value) that the number of genes involved in any given function (elements) were present by chance was obtained using the default parameters of the MAPMAN program.

Oct. and Dec. crown bud samples. The results show a significant decrease in ABA between Oct. and Dec., in line with other observations (Table 4).

\section{DAM and FT-like are reciprocally and differentially expressed during transition from para-through ecodormancy in leafy spurge}

There is growing evidence that DAM genes play a role in regulating dormancy transitions. Two clones (DV112957 and DV114890) representing different DAM genes were present on our microarrays and both were found to be differentially regulated (see Additional file 2). Probes specific to the 3' end of these genes were developed and used to probe northern blots to confirm the differential expression observed from the microarray results. The leafy spurge DAM1a gene was strongly up-regulated only in endodormant buds whereas DAM2 was induced during endodormancy and maintained at high levels through ecodormancy (Figure 3). Because the DAM1 probe was shown to have minimal but detectable cross-hybridization to a DAM2 clone (data not shown), it is unclear if the

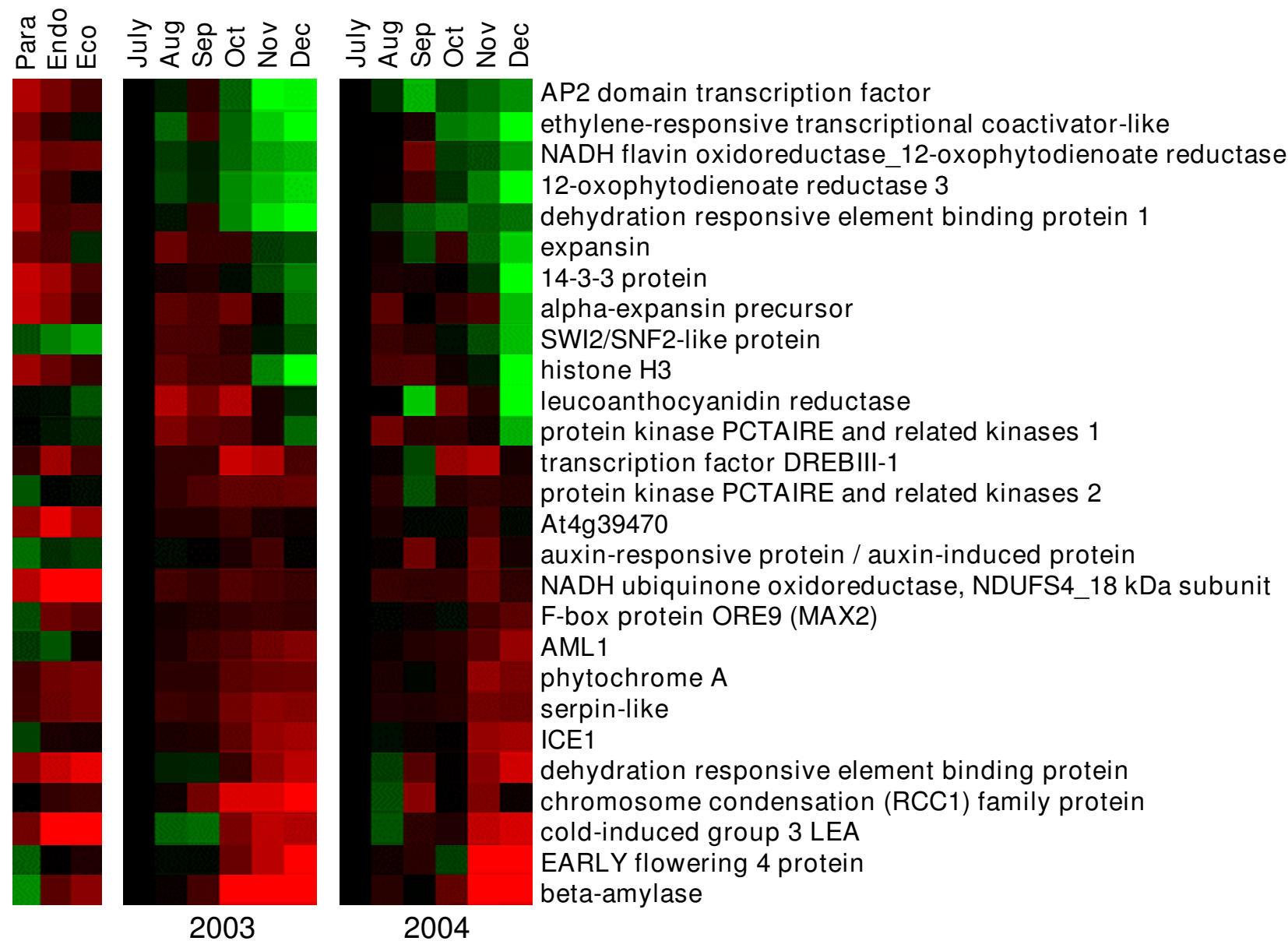

Figure 2

Confirmation of microarray expression profile by RT-PCR. RT-PCR analysis using crown bud RNA collected monthly during 2003 and 2004 was done on 27 selected genes. Relative gene expression levels are shown with high expression represented by red and low expression represented by green. 
Table 4: Average ABA levels (ng/gm $\mathrm{f}-\mathrm{wt}$ ) in buds from Oct. and Dec. 2005 and 2006.

\begin{tabular}{lllll}
\hline Oct. 2005 & Oct. 2006 & Dec. 2005 & Dec. 2006 & P value \\
\hline 97.08 & 94.4 & 14.04 & 34.65 & 0.008 \\
\hline
\end{tabular}

$P$ value equals probability that Oct. and Dec. samples are equivalent based on T-test from two to three independent samples from each time point.

upper band (DAM1b) from the blot probed with DAM1 is an alternate splice product of DAM1 (of which several are suspected) or if it is the result of cross-hybridization to other DAM family members.

FT over-expression prevents seasonal growth cessation required for endodormancy induction in poplar [11]. Because DAM genes are very similar to SVP, and SVP negatively regulates FT in Arabidopsis [19], we hypothesize that the DAM genes may negatively regulate FT expression. As an initial test of this hypothesis, we characterized and compared the expression of an FT-like gene from leafy spurge to that of the DAM genes to determine if they were reciprocally expressed. Quantitative RT-PCR on the same RNA used for northern blot expression analysis of DAM1 and DAM2 demonstrated that the FT-like gene was downregulated in crown buds of leafy spurge concomitantly with the induction of DAM gene expression (Figure 3 ).

\section{Discussion \\ Cell cycle and cold responsive genes are differentially expressed during dormancy transitions}

Approximately 50\% of the differentially-expressed genes identified by our microarray analysis show a consistent pattern of incremental induction or repression during the transitions from paradormancy through to ecodormancy. However, about a third of the genes showed their greatest change in expression in the transition from the paradormant state to the endodormant state (see Additional file $3 a$ ). The timing of this transition usually coincides with decreasing night time temperatures. Thus, it was not surprising to see a majority of the genes involved in cold hardening such as ICE1, DREB and the type 3 LEA genes are up-regulated during the transition from para- to endodormancy (Figure 4, see Additional file 3a). Likewise, many of the genes involved in cell division are down-regulated during the transition between endodormancy and ecodormancy (see Additional file 3c). Previous studies have shown that HISTONE H3 is strongly down-regulated late in endodormancy or early in ecodormancy [2]. The microarray results show a similar pattern of expression for most of the growth-responsive genes (Figure 4). Combined, these expected results suggest that the analysis of the arrays was appropriate for identifying differentiallyexpressed genes.
Intriguingly, Espinosa-Ruiz [33] found that endodormancy induction brought about reduced transcript levels of cell cycle genes, but under conditions of ecodormancy these same genes were not repressed. However, unlike our study, ecodormancy in the Espinosa-Ruiz study was brought about by SD, whereas cold was the primary signal maintaining ecodormancy in our study. Thus, the different environmental conditions that maintain ecodormancy in these two studies appear to have different impact on cell division. However, data collected by Druart [24] on cambial meristems indicated that cell cycle genes were down-regulated during the transition from growth to endodormancy, and that the levels then stayed low or increased slightly during ecodormancy.

Several notable growth regulating genes that were preferentially expressed in ecodormant buds (see Additional file 2) included a RETINOBLASTOMA-like (RB-like) protein, GROWTH REGULATING FACTOR5 (GRF5), and ARABIDOPSIS MEI2-LIKE1 (AML1). RB is involved in cell cycle inhibition and acts both through sequestration of several E2F transcription factor family members-positive regulators of cell division, and through chromatin modification of key cell cycle regulatory genes [34,35]. GRF5 encodes a putative transcription factor that is involved in regulating leafy growth and morphology [36] and AML1 is a MEIOSIS2-like (MEI2-like) RNA-binding protein gene, required for meiosis and vegetative development and whose protein interacts with RAPAMYCIN-TOR (RAP$T O R)$, another protein involved in regulating cell division $[37,38]$. It is surprising that RB-like, GRF5 and AML1 are preferentially expressed in a dormancy state where many of the genes involved in active growth such as histones, cyclins and cyclin dependent kinases are repressed. Our observations can be interpreted to suggest that these particular growth-regulators are activated by conditions besides growth induction, and may be turned on primarily in response to signals regulating growth competency such as extended cold. Extended cold is known to induce growth competency in many perennial buds through unknown mechanisms. These genes may provide a convenient place to begin investigating this process. It will also be of interest to identify some of the targets regulated by these genes and determine if they are also preferentially expressed in dormant buds, or if they are maintained in a suppressed state.

\section{Circadian responses associated with seasonal dormancy transitions}

The observation that several circadian regulatory genes are differentially expressed during dormancy transitions was not surprising (see Additional file 2). However, the fact that many of them were differentially expressed in underground buds and that all of them were up-regulated following the paradormancy to endodormancy transition 

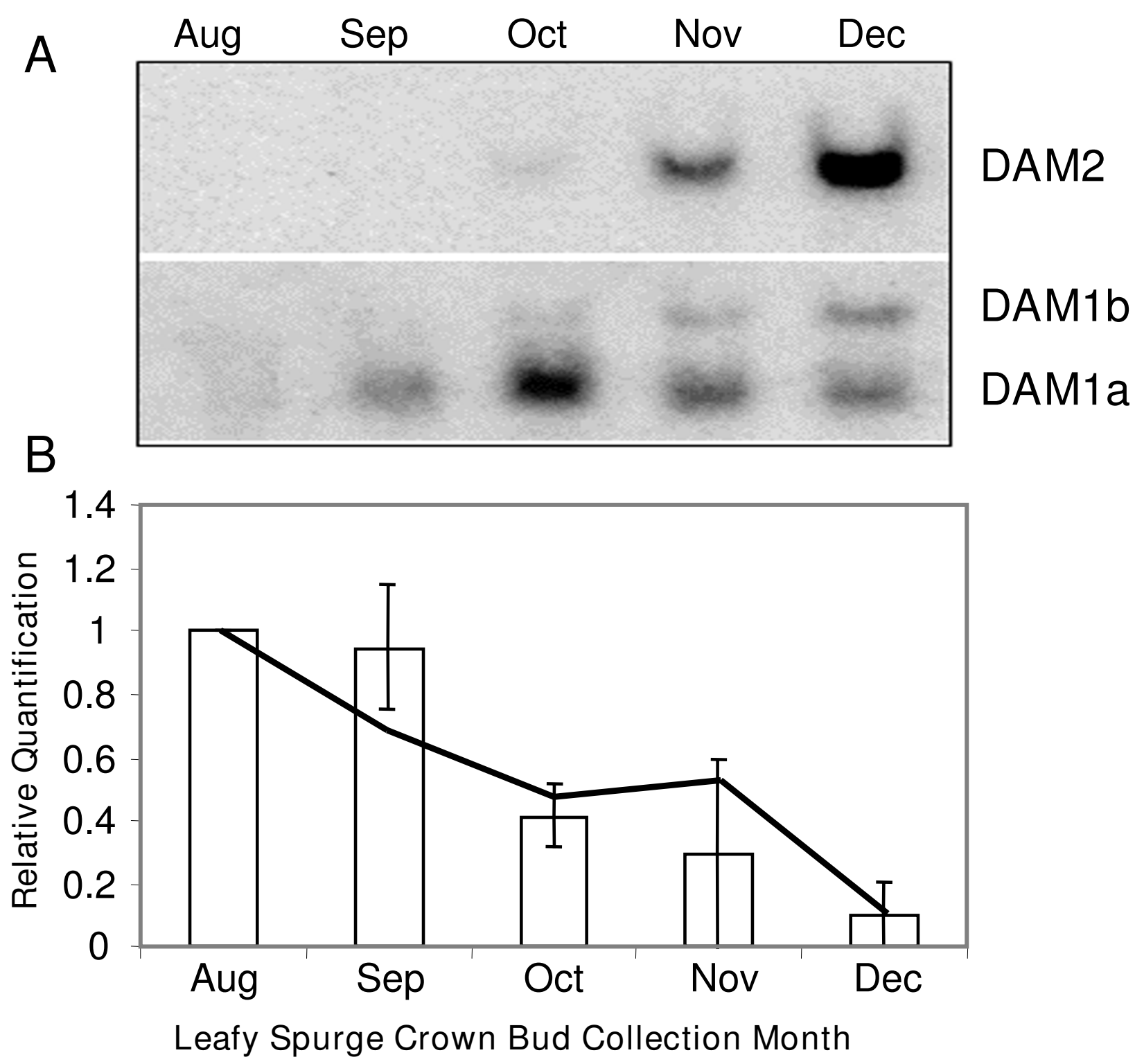

Figure 3

Comparison of DAM gene and FT expression through dormancy transitions. A) northern blot analysis of DAMI and DAM2 expression over a representative seasonal time course (2004) in leafy spurge. B) Bars show relative RT-PCR analysis of FT expression over 3 years with the line showing expression during the 2004 year. Error bars represent standard deviation of yearly expression pattern.

was initially surprising. However these results are consistent with studies in chest nut (Castanea sativa Mill.) that indicated constitutive expression of circadian clock genes during winter dormancy [39]. Although crown buds do appear to turn green and activate several photosynthetic genes such as LIGHT HARVESTING CHLOROPHYLL A/BBINDING PROTEIN during ecodormancy $[2,40]$, it was surprising to see changes in putative circadian responses in organs that are often below the soil surface. Also, the coordinated expression changes in genes such as
GIGANTEA (GI), FLAVIN BINDING KELCH REPEAT FBOX1 (FKF1), CONSTANS (CO), and EARLY FLOWERING4 (EFL4) would be expected, as would expression of PHYA, CCA1, and the PRRs [29]. However, GI, FKF1, and EFL4 are all directly or indirectly negativelyregulated by CIRCADIAN CLOCK ASSOCIATED1 (CCA) [29]. More work is needed to determine if these genes are functional orthologues of the Arabidopsis genes and to determine if other environmental, physiological, or devel- 


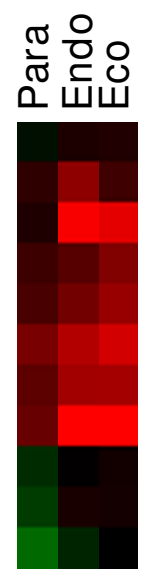

\section{Cold-regulated genes}

SOS2-like protein kinase PKS2

transcription factor DREBIII-1

LEA protein in group 3

cold-inducible CIC protein

ERD4 protein

dehydration responsive element binding protein

low temperature and salt responsive protein

cold-induced group 3 LEA

dehydration-responsive protein-related

ICE1

ERD1/XPR1/SYG1 family protein

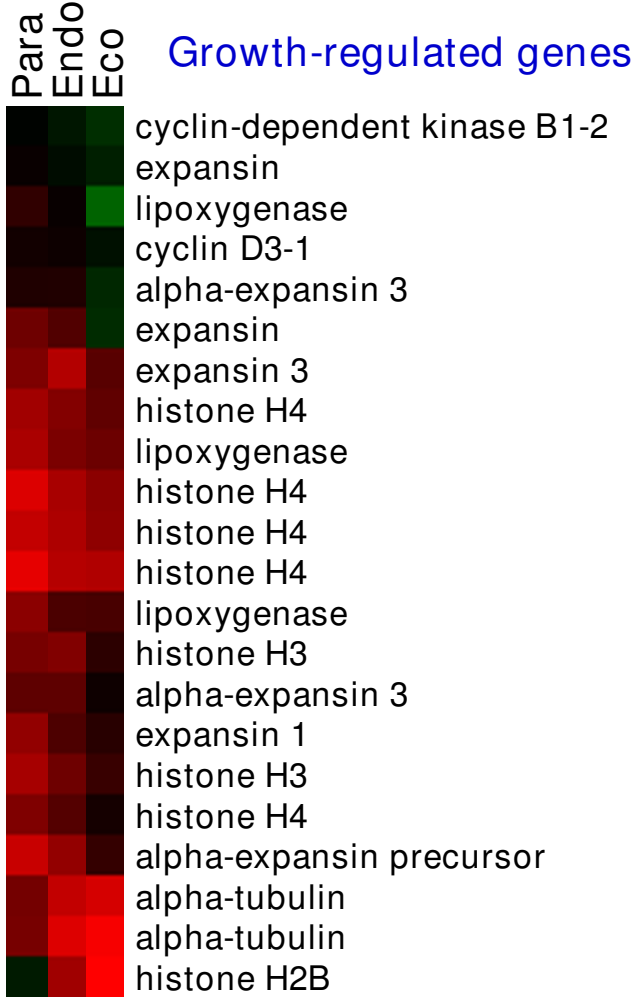

\section{Figure 4}

Heat map diagram of relative gene expression levels for probable cold-regulated and growth-regulated genes. Red color indicates relative increase in expression, and green color represents relative decrease in expression.

opmental signals are modifying the expected expression pattern of these genes in the underground buds.

\section{Conserved regulation of flowering and dormancy genes in perennials}

Perhaps the most interesting result from these studies is the finding that DAM genes are differentially expressed during dormancy transitions in leafy spurge, poplar, potato, and raspberry. The importance of this differential expression was not obvious when each study was considered on its own. Initial comparisons between our data set and the data set from raspberry identified similar MADSbox genes as differentially expressed in both species. Thus, an effort was taken to catalogue DAM gene expression in other species as studies were made available. In raspberry, a DAM-like gene was down-regulated upon dormancy release [16]. Another DAM-like gene was reported to be up-regulated in poplar after 4 weeks under dormancyinducing SD conditions (albeit not significantly) and was significantly up- or down-regulated in $A B I 3$ under- and over-expressing lines respectively [23]. Moreover, the same poplar gene was significantly up-regulated in the cambial meristem upon endodormancy induction and then down-regulated upon the transition from endodormancy to ecodormancy [24]. A close relative, MADS16, was identified as up-regulated in potato tuber meristems during the transition from endodormancy to growth [25]. However, our results provide the first evidence that different members of this gene family may have variable expression patterns through seasonal dormancy transitions (Figure 3a).

Although conserved regulatory gene expression patterns are suggestive of a functional role, such data is only correlative. Direct evidence that DAM genes are regulating dormancy comes from work on the evg mutation in peach. The evg mutation prevents terminal peach buds from going dormant in the fall [13]. The locus containing the evg mutation has recently been cloned and sequenced $[14,15]$. Sequencing through this locus indicated that the main lesion was a deletion of a series of tandomly repeated copies of DAM genes. Our data highlights the fact that not only are these genes required for endodormancy induction, but that DAM genes are induced by environmental signals known to regulate endodormancy. 
SD and cold temperatures regulate dormancy in a species specific manner. SD rather than cold temperature is the primary signal regulating endodormancy induction in poplar [41]. In some rosaceous species such as apple and pear, cold temperatures are the primary environmental signal inducing endodormancy [42]. Experiments are currently underway to determine the environmental parameters required for endodormancy induction in leafy spurge, however preliminary experiments suggest SD is not sufficient for endodormancy induction. However, it should be noted that there is evidence of synergistic cross-talk between SD and low-temperature signalling pathways [43], and thus it is possible, if not likely, that cold and day length signalling mechanisms regulating dormancy may be shared across species. It will be interesting to compare $D A M$ gene regulation in species that primarily respond to either light or temperature signals for dormancy induction.

We hypothesize that DAM proteins regulate dormancy transitions through interaction with FT-like genes. In Arabidopsis, SVP may be involved in sensing changes in ambient temperatures and transducing this information to regulate flowering by inhibiting $F T$ expression through binding of CArG motifs [19]. In poplar, over expression of FT inhibits growth cessation and bud set associated with seasonal bud dormancy [11]. Expression of FT or FT-like genes such as CENL1 are down-regulated in grape buds (Fennell, personal communication), poplar $[12,23]$, and spruce [44] during induction of endodormancy. Our paradigm predicts that $F T$ should be reciprocally expressed with DAM genes. However, no FT genes were present in the leafy spurge or cassava EST databases and thus not present on the microarrays.

As an initial test of our hypothesis, we cloned and characterized the expression of an FT-like gene from leafy spurge (Accession \# EU707393). Several cDNA clones and a genomic clone (Accession \# EU707394) contained the 3' end of $F T$-like genes ( $49 \%$ of the coding region). We suggest our clones represent $F T$ orthologues rather than orthologues of the closely related gene TFL because 1) the FT-like genomic clone contained an intron with similar size and location to the last intron in the Arabidopsis FT gene, 2) a BLASTX search of the Arabidopsis database demonstrated that $F T$ was the top blast hit (with a score of 2e39 ) to our clones, 3) cluster analysis of DNA sequence placed our FT-like genes with other FT genes and away from related TFL genes, including several full-length $T F L$ like genes from leafy spurge (Accession \#s DV157402, DV135948, and DV121805), and 4) our FT-like gene is expressed preferentially in leaves and is diurnally regulated as would be expected of a functional FT orthologue (see Additional file 5, 6, 7). Work is continuing to clone full length copies of FT-like genes from leafy spurge and confirm their functionality. However, consistent with our hypothesis, the FT-like gene is reciprocally regulated with expression of our DAM genes.

Some questions remain concerning the role of FT and DAM genes through dormancy transitions. Although it seems likely that DAM genes and FT may play a direct role in seasonal growth cessation and possibly in the transition from paradormancy to endodormancy, it should be noted that at least DAM2 is expressed well into ecodormancy. Likewise, FT-like is also down-regulated well into ecodormancy. Thus, the DAM gene and FT-like probably do not play any role in the transition to growth competence that occurs during the shift from endodormancy to ecodormancy. This suggests that there are other signals and mechanisms involved in controlling the transition from endo- to ecodormancy and concurrent induction of floral and growth competence in leafy spurge.

Work is currently underway to identify the cis- and transacting signals regulating DAM gene expression in leafy spurge and to study the impact of constitutive and dominant negative regulation of the leafy spurge DAM genes on bud dormancy and flowering in leafy spurge and several heterologous systems. Likewise, work is underway to functionally characterize and to clone the regulatory regions of the FT-like genes from leafy spurge and to determine if they contain the conserved CArG motifs, and to determine if these FT-like genes are directly regulated by $D A M$ genes from leafy spurge during induction of dormancy.

\section{Chromatin remodelling in dormancy transitions}

Given the similarities between the environmental and molecular signals regulating both flowering and dormancy, it is tempting to speculate that the same mechanisms regulating chromatin remodelling processes and genes regulating vernalization and flowering competence in Arabidopsis, also regulate the re-initiation of growth competence in vegetative buds of perennials following extended cold treatments. Numerous genes involved in chromatin remodelling are differentially expressed during dormancy transitions in leafy spurge and other species. A member of the chromosome condensation (RCC1) family of proteins which interact with histones is strongly upregulated in leafy spurge crown buds during induction of endodormancy. Interestingly, a similar protein is downregulated in potato buds transitioning from endodormancy to growth [25]. Additionally, RB-related proteins, also affecting chromatin remodelling as previously discussed, are differentially-expressed in leafy spurge, poplar and potato (see Additional file 8).

Ruttink [23], found four different chromatin remodelling genes that were significantly up-regulated prior to endo- 
dormancy induction, but considered the induction to be too early to impact the transition to endodormancy. However, in their studies, they did not look at dormancy release, and thus it is impossible to determine if these or other chromatin remodelling genes might be differentially expressed in response to extended cold treatments. Law and Suttle [45], noted that dormancy release in potato was concomitant with increased histone acetylation. Likewise, chromatin remodelling was suggested by Druart [24] to explain the large scale changes in transcription observed in poplar cambial meristems during seasonal dormancy transitions. In both leafy spurge and poplar, a SWI2/SNF2-like gene similar to At5g66750, was significantly down-regulated (steadily through dormancy transitions in leafy spurge and after 4 weeks of SD in poplar). SWI2/SNF2 proteins are needed as part of a complex known to modify chromatin and enhance expression of specific genes [46].

\section{Auxin responses in seasonal dormancy transitions}

Other comparisons between the transition from paradormancy to endodormancy and from endodormancy to ecodormancy indicate that five of the six genes with blast hits to genes involved in auxin responses show the greatest differential expression during the paradormancy to endodormancy transition. MAPMAN analysis also indicated an increase in expression of genes involved in auxin metabolism (Table 3). This also might be expected since as the plants senesce during the transition into endodormancy, auxin transport from the above ground tissue would be reduced. Indeed, a similar argument was made to explain observed induction of a DORMANCY-ASSOCIATED, AUXIN-REPRESSED (DAAR) gene in crown buds of leafy spurge [2]. DAAR genes are known to be repressed by auxin in several plant systems $[47,48]$. These observations are consistent with findings of Schrader [22], suggesting that auxin responses may be modulated in both cambial meristem and adventitious buds during endodormancy, and $\mathrm{Li} \mathrm{[49]} \mathrm{that} \mathrm{indicated} \mathrm{auxin} \mathrm{levels} \mathrm{were} \mathrm{reduced} \mathrm{in} \mathrm{ter-}$ minals buds of silver birch (Betula pendula) during shortday-induced dormancy.

BLASTX analysis of the differentially-expressed genes indicated down-regulation of genes involved in flavanoid biosynthesis in buds that have passed from paradormancy through to ecodormancy (see Additional file 2). Flavanoids have been implicated in inhibition of polar auxin transport [50-53]. The ability of buds to export auxin has been hypothesized to be the driving force behind the signals regulating apical dominance [54]. In potato buds, auxin levels steadily increase during dormancy and then drop off after dormancy is released [55]. Combined, these data suggest that as the buds lose apical dominance, they may be preparing to export auxin even when the buds are not transitioning into an actively growing state. These data support earlier microarray studies on root buds of leafy spurge which indicated that flavanoid biosynthetic genes were down-regulated following release from paradormancy [56].

It should be noted, however, that although several AUX/ $I A A$-like genes are down-regulated during the transition from paradormancy to endodormancy, a gene with similarity to MORE AXILLARY BRANCHES (MAX2) that encodes a protein involved in inhibition of auxin transport $[57,54]$, is up-regulated (see Additional file 2). Thus, it appears that there are opposing mechanisms involved in auxin production, transport, and perception acting simultaneously during dormancy transitions, and more work will be needed to ascertain the relevance of this hormone in seasonal dormancy transitions.

\section{$J A$, ethylene, and $A B A$ responses in seasonal dormancy transitions}

Many of the genes associated with cold, drought and ABA responses are preferentially expressed later during endoand ecodormancy (Figure 4). From work in poplar and potato, there appears to be an emerging picture that a transient spike in ethylene (or ethylene perception) precedes, and is necessary for, the initiation of endodormancy $[58,23]$. A role of ethylene in ABA-induced growth inhibition in systems other than bud endodormancy has been previously hypothesized [59]. Work on ABA accumulation in Citrus suggests that ethylene may directly induce the key ABA biosynthetic gene 9-CIS-EPOXYCAROTENOID DIOXYGENASE (NCED1) [60]. Our data appears consistent with the above theory in that there are at least 10 genes associated with ethylene production or ethylene responses that are most highly expressed during paradormancy, but which were repressed later during endo- and ecodormancy.

Intriguingly, ABA levels were elevated during endodormancy and dropped following the transition to ecodormancy (Table 4). Loss of ABA through ecodormancy has been observed in several plant species [30-32]. However, all but four expected ABA-regulated genes are induced during the endo- to ecodormancy transition (see Additional file 2), and of the four that showed reduced expression, only one (DREBIII) is significantly down-regulated. A possible explanation for this observation is that many ABA-regulated genes are also cold-regulated, and there is evidence that cold and ABA regulates these genes through independent pathways [61].

The high numbers of JA-regulated genes suggest a possible role for this hormone in seasonal dormancy progression (see Additional file 2). JA is generally associated with wounding, and there are also reports that JA acts synergistically with ethylene [62-64]. JA is also known to induce 
vegetative storage protein expression in numerous plant systems [65-68]. Likewise, JA is known to induce tuber formation in potato [69]. Thus, increased JA perception during paradormancy might be needed to prepare the plants for winter. Vegetative storage proteins were also the most over-represented among the differentially-expressed genes based on MIPS FunCat designation (Table 2). A similar argument was noted for the increase in differentially-expressed JA-responsive genes during the transition into endodormancy in poplar cambial meristems [24].

\section{Conclusion}

These results provide the first indication of changes in gene expression in underground buds of a herbaceous perennial associated with seasonal dormancy transitions. Changes in gene expression suggest numerous hormonal, physiological, and developmental responses occur during transitions from paradormancy through endodormancy and into ecodormancy including alterations in responses to ABA, JA, and auxin, and in cell cycle, cold-hardening, transport, and glycolysis. Additionally, comparison between the transcriptome changes observed in our experiments and those from similar dormancy transitions in other plant species allowed the identification of DAM genes that encode a specific group of MADS-box transcription factors associated with endodormancy induction. The fact that DAM genes are similar to another MADS-box gene (SVP) that negatively regulates FT in Arabidopsis, and the finding that over-expression of $F T$ in poplar prevents seasonal growth cessation led to the hypothesis that induction of DAM genes may be required for inhibition of FT expression. In support of this hypothesis, FT expression in leafy spurge crown buds was co-ordinately down regulated as DAM gene expression was induced.

\section{Methods}

\section{Plant material}

A population of leafy spurge plants was initiated from cuttings of the same ND001 line used in several previous studies on leafy spurge bud growth and development [2]. Plant were maintained in an outside garden plot in Fargo, ND and supplemental water and fertilizer was added as needed for several years prior to initial bud collections. Crown buds were collected monthly (August through December from 2002-2006). Buds were always collected between 10:00 AM and 1:00 PM for all samples. Environmental data at and around the time of bud collections are noted (see Additional file 9). Bud samples were stored immediately in liquid $\mathrm{N}_{2}$ and then at $-80 \mathrm{C}$ until RNA extraction.

\section{ABA extraction and analysis}

Each sample consisted of 0.5 to 0.6 gm of pooled buds collected in Oct. or Dec. 2005 and 2006. Samples were immediately frozen in liquid nitrogen. Two or more sam- ples were analyzed in duplicate for each time point. The tissues were thawed at $4 \mathrm{C}$ in $80 \%(\mathrm{v} / \mathrm{v})$ aqueous acetone, homogenized, extracted, purified, and the ABA content quantified by HPLC-MS using an internal standard of 50 ng $\left[{ }^{2} \mathrm{H}\right]_{6}-(+)$-ABA (OlChemIm Ltd, Czech Republic) as described by Destefano-Beltran [70].

\section{RNA extraction and microarray analysis}

Crown buds were ground to a fine powder in liquid $\mathrm{N}_{2}$ and RNA was extracted using the pine tree extraction protocol [71]. RNA quality and quantity was confirmed by spectrophotometry and denaturing agarose gels. Labelled cDNA was prepared from $30 \mu \mathrm{g}$ of total RNA using the Alexa Fluor cDNA labelling kit (Invitrogen, Carlsbad, CA) according to manufacture's protocols. Labelled cDNAs were hybridized to a custom made $23 \mathrm{~K}$ element microarray that contained 19,808 unigenes from the leafy spurge EST database [72] and an additional 4,129 unigenes from a cassava EST database [73]. The cassava unigenes did not have any obvious similarity to available leafy spurge ESTs, however, many of them showed strong hybridization with labelled leafy spurge cDNA [26]. A rolling circle dye swap hybridization scheme [74] was used to compare gene expression between samples. Microarray hybridization was visualized using an AFFYmetrix 428 scanner (see Additional file 10) and spot intensities and background was quantified using Affymetrix Jaguar software. GeneMaths XT 5.1 software (Applied Maths Inc. Austin, TX) was used for statistical analysis and clustering of the dataset.

Hybridization intensities were $\log 2$ transformed, and arrays were centred and normalized against each other. Arrays were grouped by month and ANOVA was used to identify genes that were differentially expressed $(\mathrm{p}<$ $0.005)$. Cluster analysis of expression pattern for differentially-expressed genes was done to identify likely paradormant, endodormant and ecodormant samples. The entire data set was then regrouped according to dormancy state, and subjected to ANOVA again to identify genes that are differentially expressed $(\mathrm{p}<0.005)$ through the dormancy transitions. To identify genes with significant differential expression during specific dormancy states, T-tests were used to determine $\mathrm{p}$-values that a given gene was differential in one dormant state, but not differential between the other dormant states (ie. paradormant specific genes would have $\mathrm{p}<0.005$ between paradormancy and endodormancy and $\mathrm{p}>0.005$ between endodormancy and ecodormancy).

Putative Arabidopsis orthologues were identified by BLASTX homology with a cut off of 1.0 E-5. Likewise, TBLASTX was used to identify similar genes present on other microarrays used for dormancy studies (cut off of 1.0 E-5) (see Additional file 8). Where possible contigs 
represented by spotted cDNAs were used for the BLAST comparisons. AGI designations for Arabidopsis genes were used in conjunction with MAPMAN to identify biochemical and signalling pathways represented by the differentially-expressed genes.

\section{RT-PCR and northern blot expression analysis}

Primers were designed (see Additional file 11) to specifically amplify genes identified as differentially expressed using sequences from the EST database[72,73]. cDNA from bud samples collected during the designated years was prepared, quantified, and checked for quality by separation on agarose gels. Equal amounts of cDNA were used in each reaction and reactions were run in triplicate. SYBR green and the endogenous ROX reference dye were used to determine relative CT values. For RT-PCR of the FT-like gene, the primer-probe combination was designed by Applied Biosystems Custom Taqman(R) Gene Expression Assay Service based on sequence from the genomic clone: reverse primer GCTGGTCTTGGACTCTCATACC, forward primer GGTGACTGATATTCCAGCAACTACT, and probe TCTCTTGCCCATAGCTTG. The probe was designed to span the last intron in the gene to eliminate signal from contaminating genomic DNA or un-spliced RNAs.

Probes for northern analysis were produced by PCR from full length cDNA clones of DAM1 (EU334633) and DAM2 (EU339320). Primers for DAM1 specific probes were (5') GAGTTATCTACTCTTTGTGATG and (3') CAATTGTCAACTATTTATTGGATGG and amplified a 260 bp fragment containing a portion of the coding region (of which 83 nt were common with DAM2) plus the 3' UTR. DAM2 primers were (5') TGACTCGGGTGATCGAAAG and (3') AGTCGCTCGTTCTCTTCC and amplified a 313 bp product covering the 3 ' portion of the coding region (none of which was homologous to DAM1). These fragments were radio-labelled and used to probe a northern blot containing equal loadings ( $10 \mu \mathrm{g}$ each) of total crown bud RNA (collected monthly in 2004) separated on a denaturing agarose gel.

Accession numbers for sequence and gene expression data. GEO series \# GSE8849, Genbank \#s DAM1 EU334633, DAM2 - EU339320, EeFT2L - EU707393, EeFT2gs - EU707394, EeFT10 - EU707395, EeTFL1-3 DV157402, DV135948, and DV121805

\section{Authors' contributions}

DPH conceived of the study, participated in its design, drafted the manuscript, and performed the microarray hybridization and analysis. WSC performed and analyzed the Real-time PCR data. JCS performed and analyzed the ABA quantification. JT assisted with the bioinformatics. JVA provided the plant material for these experiments and assisted in the experimental design.

\section{Additional material}

\section{Additional file 1}

Differentially expressed genes. List of differentially-expressed genes, gene expression data, and gene annotation.

Click here for file

[http://www.biomedcentral.com/content/supplementary/1471-

2164-9-536-S1.xls]

\section{Additional file 2}

Differentially expressed genes specifically mentioned in text. List of genes with functional annotations specifically mentioned in the text. Gene expression data, and gene annotation is noted for each.

Click here for file

[http://www.biomedcentral.com/content/supplementary/14712164-9-536-S2.xls]

\section{Additional file 3}

Genes differentially expressed specifically during para-endo- and ecodormancy. List of gene expression data and gene annotation for genes with significant expression patterns during paradormancy ( $3 a$ ) endodormancy (3b) and ecodormancy (3c).

Click here for file

[http://www.biomedcentral.com/content/supplementary/14712164-9-536-S3.xls]

\section{Additional file 4}

Common differentially expressed genes from dormancy transitions in other species. List of differentially-expressed genes with blastX hits to differentially-expressed genes in datasets from dormancy transitions for other plant species.

Click here for file

[http://www.biomedcentral.com/content/supplementary/14712164-9-536-S4.xls]

\section{Additional file 5}

Cluster analysis of FT and FT-like genes from various species. Phylogenetic analysis of FT-like and TFL-like genes from leafy spurge and various other species. Nucleotide sequence data from four different $\mathrm{FT}$-like genes obtained from leafy spurge (3'Race-EeFT10 (Accession \# EU707395), amplification of genomic DNA-EeFTgs (Accession \# EU707394, and amplification from cDNA-EeFT2lb (Accession \# EU707393) were aligned to several FT-like and TFL-like genes from leafy spurge, poplar, castor bean, Arabidopsis, potato, tomato, and apple using ClustalX. Bootstrap values were generated as shown (1000 iterations). Click here for file

[http://www.biomedcentral.com/content/supplementary/14712164-9-536-S5.ppt]

\section{Additional file 6}

Sequence data from leafy spurge and Arabidopsis FT genes. Genomic sequence from amplified region of FT-like gene from leafy spurge (top) and equivalent region from genomic DNA sequence of arabidopsis FT gene (bottom). Intron sequence is shown in bold lower case. Identical bases are noted in blue.

Click here for file

[http://www.biomedcentral.com/content/supplementary/14712164-9-536-S6.ppt] 


\section{Additional file 7}

Northern analysis of FT expression in leafy spurge.Supplemental Figure S3: Northern analysis of RNA collected from leaf tissue approximately $7 \mathrm{hr}$ after dawn (D) and $3 \mathrm{hr}$ after dusk (N) from outdoor-grown flowering competent (F) and greenhouse-grown flowering incompetent (NF) plants. Northern blot was probed with P32 labelled amplified FT-like cDNA fragment (EeFTgb).

Click here for file

[http://www.biomedcentral.com/content/supplementary/14712164-9-536-S7.ppt]

\section{Additional file 8}

All differentially expressed genes from dormancy transitions in other species. List of all differentially-expressed genes in poplar, leafy spurge, potato, raspberry, and grape. Rows contain differentially expressed genes from represented species. All genes in a given row are matched with BLASTX scores of $<10 E-5$.

Click here for file

[http://www.biomedcentral.com/content/supplementary/14712164-9-536-S8.xls]

\section{Additional file 9}

Collection dates and conditions. Dates and weather conditions at and prior to the time of bud collections.

Click here for file

[http://www.biomedcentral.com/content/supplementary/1471-

2164-9-536-S9.xls]

\section{Additional file 10}

Normalized expression data. List of all spots on the microarray along with gene expression data and gene annotation.

Click here for file

[http://www.biomedcentral.com/content/supplementary/14712164-9-536-S10.xls]

\section{Additional file 11}

Primers and reaction conditions for quantitative RT-PCR. List of primer sequences and PCR conditions used for RT-PCR confirmation of differential gene expression for selected genes.

Click here for file

[http://www.biomedcentral.com/content/supplementary/14712164-9-536-S11.xls]

\section{Acknowledgements}

We would like to thank Drs. Michael Campbell, Anne Fennell, and those at HortResearch (Marion Wood, Eric Walton, Robert Schaffer, and others) for graciously sharing their data with us prior to publishing. We would also like to thank Drs. Antje Rohde, and Anne Fennell for constructive suggestions in writing this manuscript. This work was entirely funded by the US Department of Agriculture, Agricultural Research Service.

\section{References}

I. Lang GA, Early JD, Martin GC, Darnell RL: Endodormancy, Paradormancy, and Ecodormancy - Physiological Terminology and Classification for Dormancy Research. Hortscience 1987 22(3):37|-377.

2. Anderson JV, Gesch RW, Jia Y, Chao WS, Horvath DP: Seasonal shifts in dormancy status, carbohydrate metabolism, and related gene expression in crown buds of leafy spurge. Plant Cell and Environment 2005, 28( I 2): I567-I578.
3. Horvath DP: Role of mature leaves in inhibition of root bud growth in Euphorbia esula L. Weed Science 1999, 47(5):544-550. 4. Sorefan K, Booker J, Haurogne K, Goussot M, Bainbridge K, Foo E, Chatfield S, Ward S, Beveridge C, Rameau C, et al.: MAX4 and RMSI are orthologous dioxygenase-like genes that regulate shoot branching in Arabidopsis and pea. Genes \& Development 2003, I7( I 2): | 469-| 474

5. Beveridge CA: Axillary bud outgrowth: sending a message. Current Opinion in Plant Biology 2006, 9(I):35-40.

6. Horvath DP, Chao WS, Anderson JV: Molecular analysis of signals controlling dormancy and growth in underground adventitious buds of leafy spurge. Plant Physiol 2002, I 28(4): | 439-| 446.

7. Chao WS, Serpe MD, Anderson JV, Gesch RW, Horvath DP: Sugars, hormones, and environment affect the dormancy status in underground adventitious buds of leafy spurge (Euphorbia esula). Weed Science 2006, 54(1):59-68.

8. Chouard P: Vernalization and Its Relations to Dormancy. Annual Review of Plant Physiology and Plant Molecular Biology 1960, I I:19|-238

9. Horvath DP, Anderson JV, Chao WS, Foley ME: Knowing when to grow: signals regulating bud dormancy. Trends Plant Sci 2003 8(I I):534-540.

10. Rohde A, Bhalerao RP: Plant dormancy in the perennial context. Trends in Plant Science 2007, I 2(5):217-223.

II. Bohlenius H, Huang T, Charbonnel-Campaa L, Brunner AM, Jansson $\mathrm{S}$, Strauss $\mathrm{SH}$, Nilsson $\mathrm{O}$ : CO/FT regulatory module controls timing of flowering and seasonal growth cessation in trees. Science 2006, 3 I 2(5776): I040- 1043.

12. Ruonala R, Rinne PLH, Kangasjarvi J, Schoot C van der: CENLI expression in the rib meristem affects stem elongation and the transition to dormancy in Populus. Plant Cell 2008, 20(I):59-74.

13. Diaz MD: Vegetative and reproductive growth habits of evergreen peach trees in Mexico. Proceedings from the XIX International Horticulture Congress 1974, I 8:525

14. Bielenberg DG, Wang Y, Fan S, Reighard GL, Scorza R, Abbott AG: A deletion affecting several gene candidates is present in the Evergrowing peach mutant. J Hered 2004, 95(5):436-444.

15. Bielenberg DG, Wang Y, Li ZG, Zhebentyayeva T, Fan SH, Reighard GL, Scorza R, Abbott AG: Sequencing and annotation of the evergrowing locus in peach [Prunus persica (L.) Batsch] reveals a cluster of six MADS-box transcription factors as candidate genes for regulation of terminal bud formation. Tree Genetics \& Genomes 2008, 4(3):495-507.

16. Mazzitelli L, Hancock RD, Haupt S, Walker PG, Pont SDA, McNicol J, Cardle L, Morris J, Viola R, Brennan R, et al.: Co-ordinated gene expression during phases of dormancy release in raspberry (Rubus idaeus L.) buds. Journal of Experimental Botany 2007 , 58(5): $1035-1045$

17. Yamane H, Kashiwa $\mathrm{Y}$, Ooka T, Tao R, Yonemori K: Identification and characterization of MADS-Box genes expressed in endodormant winter buds of Japanese apricot (Prunus mume). In Plant \& Animal Genomes XVI Conference Town \& Country Convention Center, San Diego, CA; 2008.

18. Hartmann U, Hohmann S, Nettesheim K, Wisman E, Saedler H, Huijser P: Molecular cloning of SVP: a negative regulator of the floral transition in Arabidopsis. Plant Journal 2000, 2I(4):35I-360

19. Lee JH, Yoo SJ, Park SH, Hwang I, Lee JS, Ahn JH: Role of SVP in the control of flowering time by ambient temperature in Arabidopsis. Genes \& Development 2007, 2 I (4):397-402.

20. Michaels SD, Ditta G, Gustafson-Brown C, Pelaz S, Yanofsky M, Amasino RM: AGL24 acts as a promoter of flowering in Arabidopsis and is positively regulated by vernalization. Plant Journal 2003, 33(5):867-874.

21. Mathiason K, He D, Grimplet J, Venkateswari J, Galbraith DW, Or E, Fennell A: Transcript profiling in Vitis riparia during chilling requirement fulfillment reveals coordination of gene expression patterns with optimized bud break. Funct Integr Genomics 2008 in press.

22. Schrader J, Moyle R, Bhalerao R, Hertzberg M, Lundeberg J, Nilsson $P$, Bhalerao RP: Cambial meristem dormancy in trees involves extensive remodelling of the transcriptome. Plant Journal 2004, 40(2): $173-187$

23. Ruttink T, Arend M, Morreel K, Storme V, Rombauts S, Fromm J, Bhalerao RP, Boerjan W, Rohde A: A molecular timetable for 
apical bud formation and dormancy induction in poplar. Plant Cell 2007, 19(8):2370-2390.

24. Druart N, Johansson A, Baba K, Schrader J, Sjodin A, Bhalerao RR, Resman L, Trygg J, Moritz T, Bhalerao RP: Environmental and hormonal regulation of the activity-dormancy cycle in the cambial meristem involves stage-specific modulation of transcriptional and metabolic networks. Plant Journal 2007, 50(4):557-573.

25. Campbell MA, Segear E, Beers L, Knauber D, Suttle J: Dormancy in potato tuber meristems: chemically induced cessation in dormancy matches the natural process based on transcript profiles. Functional and Integrative Genomics 2008, 8:317-328.

26. Anderson JV, Delseny M, Fregene MA, Jorge V, Mba C, Lopez C, Restrepo S, Soto M, Piegu B, Verdier V, et al.: An EST resource for cassava and other species of Euphorbiaceae. Plant Mol Biol 2004, 56(4):527-539.

27. Cairns BR: Chromatin remodeling machines: similar motors, ulterior motives. Trends in Biochemical Sciences 1998, 23(I):20-25.

28. Kikis EA, Khanna R, Quail PH: ELF4 is a phytochrome-regulated component of a negativefeedback loop involving the central oscillator components CCAI and LHY. Plant Journal 2005, 44(2):300-3I3.

29. McClung CR: Plant circadian rhythms. Plant Cell 2006 , 1 8(4):792-803.

30. Wright STC: Seasonal-Changes in Levels of Free and Bound Abscisic-Acid in Blackcurrant (Ribes-Nigrum) Buds and Beech (Fagus-Sylvatica) Buds. Journal of Experimental Botany 1975, 26(91): 161-174.

31. Harrison MA, Saunders PF: Abscisic-Acid Content of Dormant Birch Buds. Planta 1975, 123(3):291-298.

32. Suttle JC: Postharvest Changes in Endogenous Aba Levels and Aba Metabolism in Relation to Dormancy in Potato-Tubers. Physiologia Plantarum 1995, 95(2):233-240.

33. Espinosa-Ruiz A, Saxena S, Schmidt J, Mellerowicz E, Miskolczi P, Bako L, Bhalerao RP: Differential stage-specific regulation of cyclindependent kinases during cambial dormancy in hybrid aspen. Plant Journal 2004, 38(4):603-6I5.

34. Shen WH: The plant E2F-Rb pathway and epigenetic control. Trends in Plant Science 2002, 7(I I ):505-5 I I.

35. Lusser A, Kolle D, Loidl P: Histone acetylation: lessons from the plant kingdom. Trends in Plant Science 200I, 6(2):59-65.

36. Horiguchi G, Kim GT, Tsukaya H: The transcription factor AtGRF5 and the transcription coactivator AN3 regulate cell proliferation in leaf primordia of Arabidopsis thaliana. Plant Journal 2005, 43(I):68-78

37. Anderson GH, Hanson MR: The Arabidopsis Mei2 homologue AMLI binds AtRaptorlB, the plant homologue of a major regulator of eukaryotic cell growth. Bmc Plant Biology 2005, 5:

38. Kaur J, Sebastian J, Siddiqi I: The Arabidopsis-mei2-like genes play a role in meiosis and vegetative growth in Arabidopsis. Plant Cell 2006, 18(3):545-559.

39. Ramos A, Perez-Solis E, Ibanez C, Casado R, Collada C, Gomez L, Aragoncillo C, Allona I: Winter disruption of the circadian clock in chestnut. Proceedings of the National Academy of Sciences of the United States of America 2005, 102(19):7037-7042.

40. Horvath DP, Anderson JV, Soto-Suarez M, Chao WS: Transcriptome analysis of leafy spurge (Euphorbia esula) crown buds during shifts in well-defined phases of dormancy. Weed Science 2006, 54(5):82I-827.

4I. Olsen JE: Mechanisms of dormancy regulation. Acta Horticulturae 2006, 727:157-166.

42. Heide OM, Prestrud AK: Low temperature, but not photoperiod, controls growth cessation and dormancy induction and release in apple and pear. Tree Physiology 2005, 25(I): 109-I|4.

43. Benedict C, Geisler M, Trygg J, Huner N, Hurry V: Consensus by democracy. Using meta-analyses of microarray and genomic data to model the cold acclimation signaling pathway in Arabidopsis. Plant Physiology 2006, I4I(4): 1219-1232.

44. Gyllenstrand N, Clapham D, Kallman T, Lagercrantz U: A Norway spruce FLOWERING LOCUS T homolog is implicated in control of growth rhythm in conifers. Plant Physiology 2007, I 44(I):248-257.

45. Law RD, Suttle JC: Changes in histone $\mathbf{H 3}$ and $\mathbf{H 4}$ multiacetylation during natural and forced dormancy break in potato tubers. Physiologia Plantarum 2004, I 20(4):642-649.
46. Pazin MJ, Kadonaga JT: SWI2/SNF2 and related proteins: ATP. Driven motors that disrupt protein-DNA interactions? Cell 1997, 88(6):737-740.

47. Stafstrom JP, Ripley BD, Devitt ML, Drake B: Dormancy-associated gene expression in pea axillary buds. Planta 1998, 205(4):547-552.

48. Reddy ASN, Poovaiah BW: Molecular-Cloning and Sequencing of a Cdna for an Auxin-Repressed Messenger-Rna - Correlation between Fruit-Growth and Repression of the AuxinRegulated Gene. Plant Molecular Biology 1990, I 4(2): I27-136.

49. Li CY, Junttila O, Ernstsen A, Heino P, Palva ET: Photoperiodic control of growth, cold acclimation and dormancy development in silver birch (Betula pendula) ecotypes. Physiologia Plantarum 2003, II 7(2):206-2/2.

50. Jacobs M, Rubery PH: Naturally-Occurring Auxin Transport Regulators. Science 1988, 24I(4863):346-349.

5I. El Euch C, Jay-Allemand C, Pastuglia M, Doumas P, Charpentier JP, Capelli $P$, Jouanin $L$ : Expression of antisense chalcone synthase RNA in transgenic hybrid walnut microcuttings. Effect on flavonoid content and rooting ability. Plant Molecular Biology 1998, 38(3):467-479.

52. Murphy A, Peer WA, Taiz L: Regulation of auxin transport by aminopeptidases and endogenous flavonoids. Planta 2000 2II(3):3I5-324.

53. Browning G: Flower Bud Dormancy in Coffea-Arabica L.2. Relation of Cytokinins in Xylem Sap and Flower Buds to Dormancy-Release. Journal of Horticultural Science \& Biotechnology I973, 48(3):297-310.

54. Bennett T, Sieberer T, Willett B, Booker J, Luschnig C, Leyser O: The Arabidopsis MAX pathway controls shoot branching by regulating auxin transport. Current Biology 2006, 16(6):553-563.

55. Sorce C, Lorenzi R, Ceccarelli N, Ranalli P: Changes in free and conjugated IAA during dormancy and sprouting of potato tubers. Australian Journal of Plant Physiology 2000, 27(4):37I-377.

56. Horvath DP, Soto-Suarez M, Chao WS, Jia Y, Anderson JV: Transcriptome analysis of paradormancy release in root buds of leafy spurge (Euphorbia esula). Weed Science 2005, 53(6):795-80I

57. Lazar G, Goodman HM: MAXI, a regulator of the flavonoid pathway, controls vegetative axillary bud outgrowth in Arabidopsis. Proceedings of the National Academy of Sciences of the United States of America 2006, 103(2):472-476.

58. Suttle JC: Involvement of ethylene in potato microtuber dormancy. Plant Physiology 1998, I I 8(3):843-848.

59. Grossmann K, Hansen H: Ethylene-triggered abscisic acid: A principle in plant growth regulation? Physiologia Plantarum 200I, II3(I):9-14.

60. Rodrigo MJ, Alquezar B, Zacarias L: Cloning and characterization of two 9-cis-epoxycarotenoid dioxygenase genes, differentially regulated during fruit maturation and under stress conditions, from orange (Citrus sinensis L. Osbeck). Journal of Experimental Botany 2006, 57(3):633-643

61. Zhang JZ, Creelman RA, Zhu JK: From laboratory to field. Using information from Arabidopsis to engineer salt, cold, and drought tolerance in crops. Plant Physiology 2004, 135(2):6|5-62|.

62. Maleck K, Dietrich RA: Defense on multiple fronts: How do plants cope with diverse enemies? Trends in Plant Science 1999, 4(6):2।5-219.

63. Pieterse CMJ, van Loon LC: Salicylic acid-independent plant defence pathways. Trends in Plant Science 1999, 4(2):52-58.

64. Thomma BPHJ, Eggermont K, Penninckx IAMA, Mauch-Mani B, Vogelsang R, Cammue BPA, Broekaert WF: Separate jasmonatedependent and salicylate-dependent defense-response pathways in Arabidopsis are essential for resistance to distinct microbial pathogens. Proceedings of the National Academy of Sciences of the United States of America 1998, 95(25):15107-15III.

65. Mason HS, Mullet JE: Expression of 2 Soybean Vegetative Storage Protein Genes during Development and in Response to Water Deficit, Wounding, and Jasmonic Acid. Plant Cell 1990 2(6):569-579.

66. Berger S, Bell E, Sadka A, Mullet JE: Arabidopsis-Thaliana Atvsp Is Homologous to Soybean Vspa and Vspb, Genes Encoding Vegetative Storage Protein Acid-Phosphatases, and Is Regulated Similarly by Methyl Jasmonate, Wounding, Sugars, Light and Phosphate. Plant Molecular Biology 1995, 27(5):933-942. 
67. Valueva TA, Revina TA, Grozdeva EL, Gerasimova NG, Il'inskaya LI, Ozeretskovskaya OL: Effects of elicitors on the accumulation of proteinase inhibitors in injured potato tubers. Applied Biochemistry and Microbiology 200I, 37(5):5I2-5I6.

68. Salzman RA, Brady JA, Finlayson SA, Buchanan CD, Summer EJ, Sun F, Klein PE, Klein RR, Pratt LH, Cordonnier-Pratt MM, et al.: Transcriptional profiling of sorghum induced by methyl jasmonate, salicylic acid, and aminocyclopropane carboxylic acid reveals cooperative regulation and novel gene responses. Plant Physiology 2005, I38(I):352-368.

69. Koda Y, Kikuta Y, Tazaki H, Tsujino Y, Sakamura S, Yoshihara T: Potato Tuber-Inducing Activities of Jasmonic Acid and Related-Compounds. Phytochemistry I99 I, 30(5): I 435- I 438.

70. Destefano-Beltran L, Knauber D, Huckle L, Suttle JC: Effects of postharvest storage and dormancy status on ABA content, metabolism, and expression of genes involved in ABA biosynthesis and metabolism in potato tuber tissues. Plant Molecular Biology 2006, 6 I (4-5):687-697.

71. Chang S, Puryear J, Cairney J: A simple and efficient method for isolating RNA from pine trees. Plant Molecular Biology Reporter 1993, II:113-116.

72. Anderson JV, Horvath DP, Chao WS, Foley ME, Hernandez AG, Thimmapuram J, Liu L, Gong GL, Band M, Kim R, et al:: Characterization of an EST database for the perennial weed leafy spurge: An important resource for weed biology research. Weed Science 2007, 55(3): 193-203.

73. Lokko Y, Anderson JV, Rudd S, Raji A, Horvath D, Mikel MA, Kim R, Liu L, Hernandez A, Dixon AGO, et al.: Characterization of an 18,166 EST dataset for cassava (Manihot esculenta Crantz) enriched for drought-responsive genes. Plant Cell Reports 2007, 26(9):1605-1618.

74. Churchill GA: Fundamentals of experimental design for cDNA microarrays. Nature Genetics 2002, 32:490-495.

Publish with Bio Med Central and every scientist can read your work free of charge

"BioMed Central will be the most significant development for disseminating the results of biomedical research in our lifetime. "

Sir Paul Nurse, Cancer Research UK

Your research papers will be:

- available free of charge to the entire biomedical community

- peer reviewed and published immediately upon acceptance

- cited in PubMed and archived on PubMed Central

- yours - you keep the copyright

Submit your manuscript here:

http://www.biomedcentral.com/info/publishing_adv.asp
BiolMedcentral 